- Achieved the rank of Associate Professor

- Active/successful clinical surgeon

- Evidence of local institutional and/or state/regional leadership ability

- Evidence of academic productivity including peer-reviewed publications and presentations at regional or national scientific meetings

- Funded research is preferable but not essential

Applications for consideration must be submitted electronically at www.aats.org by December 1, 2009. Academy participants will be selected by the Academy Committee and notified no later than February 5, 2010. The number of available slots is limited.

\section{Applications for Membership Now Available Online}

Applications for membership in the Association are now available online at www.aats.org. Interested applicants are encouraged to review the membership requirements and guidelines on the AATS Web site.

To apply for membership, a current member of the Association must act as the primary sponsor by initiating the application process in the Members Only area of the AATS Web site. Applications must be received by November 30, 2009, for consideration. All applications received after that deadline will be automatically deferred until 2010 .

\section{The Western Thoracic Surgical Association}

\section{Applications for Membership}

Applications for membership in the Association must be received by the Membership Committee Chair no later than March 1, 2010 to be considered at the 2010 Annual Meeting. Applicants must be sponsored by three members of the Association who are not members of the Membership
Committee. Application forms will be issued only to sponsoring members.

Address correspondence to:

Chair, Membership Committee

The Western Thoracic Surgical Association

900 Cummings Center

Suite 221-U

Beverly, MA 01915

978-927-8330; fax: 978-524-8890

wtsa@prri.com

\section{Thoracic Surgery Foundation for Research and Education}

The Thoracic Surgery Foundation for Research and Education was established in 1991 by the 4 leading thoracic surgery societies: American Association of Thoracic Surgery (AATS), Society of Thoracic Surgeons (STS), Southern Thoracic Surgical Association (STSA), and Western Thoracic Surgical Association (WTSA). The TSFRE represents all of thoracic surgery in the United States and its research and education initiatives support the broad spectrum of thoracic surgery. Since its inception, TSFRE has awarded and administered over $\$ 7$ million in research grants, fellowships, and career development awards for thoracic surgeons.

\section{Research Awards}

The Foundation is pleased to announce the following 2009 Research Awards:

TSFRE RESEARCH FELLOWSHIPS provide support of up to $\$ 35,000$ a year for up to 2 years for surgical residents who have not yet completed cardiothoracic surgical training.

Karen M. Kim, MD, Massachusetts General Hospital "The Effect of Donor Brain Death and Prolonged Cold Ischemia on Cardiac Allograft Tolerance in Miniature Swine,"
Alykhan Nagji, MD, University of Virginia

"Effect of Combined Histone Deacetylase Inhibitors and Proteasome Inhibitors on Epithelial-Mesenchymal-Transition in Non-Small Cell Lung Cancer Cells",

TSFRE RESEARCH GRANTS provide operational support of original research efforts by cardiothoracic surgeons who have completed their formal training and who are seeking initial support and recognition for their research program. Awards of up to $\$ 30,000$ a year for up to 2 years are made each year to support the work of an early-career cardiothoracic surgeon (within 5 years of first faculty appointment).

Ashish Shah, MD, Johns Hopkins University

“Consequences of Phosphodiesterase Type 5 Inhibition on Nitric Oxide Synthase Biochemistry in Experimental Lung Transplantation',

LUNGevity Foundation/TSFRE RESEARCH FELLOWSHIPS jointly providing support of $\$ 35,000$ a year for 2 years

Onkar Khullar, MD, Brigham \& Women's Hospital "Prevention of Nodal Metastasis in Lung Cancer via Lymphatic Trafficking of Paclitaxel-Loaded Expansile Nanoparticles"'

LUNGevity Foundation/TSFRE RESEARCH GRANTS jointly providing operational support of $\$ 30,000$ a year for 2 years. 